\title{
The ism in the Arabic Grammatical Tradition: Reflections on Its Origin and Meanings
}

\author{
SIMONA OLIVIERI (University of Helsinki)
}

\begin{abstract}
This article aims to present an overall reconstruction of the debate on the definition and etymology of Arabic ism ('noun', 'substantive'), by discussing and comparing texts from the Arabic linguistic tradition. The first part deals with the definition of the grammatical element and its functions, while the second is fully dedicated to the examination of the etymological issues, focusing on the two assumed roots of derivation for $i s m$ (namely $s-m-w$ and $w-s-m$ ). The arguments are presented through the collation of the opinions of the relevant Arabic grammarians, examining both the wider debate between the early grammatical schools of Bașra and Küfa ( $\left(2^{\text {nd }} / 8^{\text {th }}-3^{\text {rd }} / 9^{\text {th }}\right.$ centuries $)$, and the reports of the arguments as described by later scholars.
\end{abstract}

Key words: Arabic linguistic tradition, Arabic grammar, Arab grammarians, Root, Philosophy of language

\section{The parts of speech}

It is common agreement, within the Arabic linguistic tradition, that language consists of three parts of speech ('aqsām al-kaläm), namely nouns, verbs, and particles. The delineation of the tripartite vision is usually ascribed to Sībawayhi (d. 180/796) who opens the Kitāb by defining the partes orationis: "words are noun, verb, and particle." "

Each category presents differences in status and characteristics, as pointed out also by later grammarians, with distinctions mainly based on the role played within an utterance. Among the three, the noun (ism, pl. 'asmä') meets those criteria that make it a superior category, being an element "able to both operate as and receive a predicate" (ma yuhbaru bihī wa-yuhbaru 'anhu) as in 'Muhammad is our Prophet.' In this example, nouns function as both predicate and predicator, acting as mubtada' and habar in the noun clause.

Conversely, verbs $\left(f i^{c} l\right.$, pl. 'af $a \bar{a} l$ ) and particles (harf, pl. hurüf) do not share the same features: the verb "can be used as a predicate but cannot receive one" (mā yuhbaru bihī wa$l \bar{a}$ yuhbaru 'anhu), while the particles "cannot be predicates nor receive a predicate" ( $m \bar{a} l \bar{a}$ yuhbaru bih̄̄ wa-lā yuhbaru 'anhu).

In addition to this, major distinctions rely on the fact that nouns-as well as verbshave a well-defined morphology and range of meanings, while particles are meaningful words in themselves but have no strict forms. ${ }^{2}$

1 fa'l-kalim ism wa-fill wa-harf. Kitāb, i: 1.1

2 This also relates to the difficult interpretation of Sībawayhi's definition of the harf, described as what "comes for a meaning that is neither noun nor verb" (ğ $\bar{a}^{3} a$ li-ma'nan laysa bi-sm wa-lä ficl. Kitāa, i: 


\subsection{Definition}

Sībawayhi does not provide clear definitions of the ism in the Kitāb, but-relying on a common linguistic practice-reduces his explanations to a tamtī $l{ }^{3}$, providing few examples of what may be considered a 'noun', as for instance 'man', 'horse', and 'wall' (fa'l-ism rağul wa-faras wa-häàit). ${ }^{4}$

This represents the starting point from which grammarians of later periods drew inspiration to formulate their own definitions, examining the ism according to its intrinsic features and grammatical peculiarities.

The formulation of linguistic theories is framed within the conventional grammarians debate as part of the 'igm $\bar{a} \bar{a}^{c}$ ('consensus') tradition. Being a fundamental element of the whole Arabic culture and usually widely exercised in juridical discussions, ${ }^{5}$ the 'iğma ${ }^{c}$ plays a key role also in grammatical disputes, ${ }^{6}$ where unanimity is the main criterion to state the correctness of an argument. Ibn Ğinnī (d. 392/1002) in the Hașāis ${ }^{7}$ —and with regard to a strictly linguistic framework-calls it 'iğma ${ }^{c}$ ' ahl al-baladayn ${ }^{8}$ and by doing so he circumscribes the practice to the agreement among the Bașran and the Küfan grammarians.

However, as in other fields, the explicit agreement is not the only possibility to determine a concurrence of ideas, which may also be reached with either an implicit agreement or lack of explicit disagreement. ${ }^{9}$ This might be the case of the tripartite division of the parts of speech that has never been challenged after being stated in the first place. As a matter of fact, the lack of a clear definition in the Kitāb left room to a profound discussion on the subject, so that grammarians after Sībawayhi could define the nature of the category and focus on providing further details to delineate the characteristics of the noun.

\section{What is a 'noun'?}

Lane's Lexicon describes the ism as:

1.1). The impossibility to clearly define what the grammarian meant leaves room for further and opposite interpretations. Hence, some later grammarians interpreted the element as something that-not having a meaning of its own-needs to be in combination with either a verb or a noun, while others acknowledged an inherent meaning.

3 Lit. 'quotation of examples', 'representation'.

$4 \quad K i t a \bar{b}$, i: 1.1

5 For an extensive discussion on the topic, see KAMALI 2009.

6 The close relationship between the juridical and the linguistic sciences has been extensively investigated, as by Carter who states: "The two sciences are united by a common purpose, to control linguistic and general behaviour respectively, and they share a common methodology, namely the inductive derivation of rules from a linguistic corpus and the deductive application of these universal rules to particular acts of the Muslim." CARTER 2007: 25.

7 The chapter bāb al-qawl 'alà 'iğmāa 'ahl al-'arabiyya matà yakūn huğğa is fully dedicated to this topic. (Cf. al-Hașäiș, i: 189-193).

8 al-Hașā̉iș, i: 189.

9 Suleiman 1999: 15-16. 
[...][The name of a thing; i.e.] a sign [such as maybe uttered or written] conveying knowledge of a thing [...] and a word applied to denote a substance or an accident or attribute, for the purpose of distinction [...] [or a substantive in the proper sense of this term, i.e. a real substantive; and a substance in a tropical sense of this term, i.e. an ideal substantive [...] is that which denotes a meaning in itself unconnected with any of the three times [past and present and future]: the pl. is أسمَّاء [a pl. of

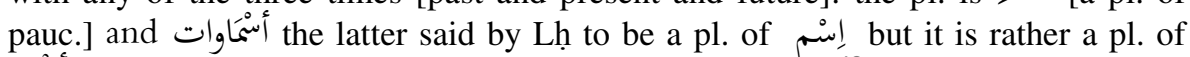
أسمْاء , for otherwise there is no way of accounting for it $[\ldots] .{ }^{10}$

This definition mostly relies on those provided by Arabic grammarians, ${ }^{11}$ for whom a noun is a word $^{12}$ which expresses a meaning but 'is neither connected with a time' ('ंayr muqtarin bi-zamān) nor is 'time part of it' (wa-laysa az-zamān ğuz'an minhā). Besides, it may be defined as a word indicating something 'perceptible' (̌̌ay' mahsūs) or 'nonperceptible' ( $\dot{g} a y r$ mahsūs) which is a means of rising into notice the thing denoted thereby, yet never referring to time. The discussion on what a 'noun' should be is rather extensive, ${ }^{13}$ and grammarians themselves record the proposition of a quantity of different positions and statements. ${ }^{14}$

Part of the discussion is related to the additional features of the noun, which may: ${ }^{15}$

1. exhibit the genitive case;

2. have the nunation;

3. be used as a vocative;

4. be marked as either defined or undefined;

5. be used as the subject of a sentence (mubtada');

6. have a predicate (musnad 'ilayhi).

Despite the different propositions, grammarians generally agree on the fundamentals of the category. Some of them add additional features or sub-categories, as al-Suyūṭi (d. 911/

10 LANE 1863, iv: 1435.

11 WEHR's definition lists several possible types of nouns, providing a full range of grammatical information. Nonetheless, for the purpose of this research it is of less interest, since it does not provide information on the debate on etymology.

12 'Word' is here meant as the translation of Arabic kalima, but also of lafz, 'sound', 'expression'. For an extensive discussion on the rendering of word, see LEVIN 1986 and LANCIONI \& BETTINI 2011.

13 For more arguments on this, see al-DAHDAH 1992 and ḤASAN 2004.

14 ḤASAN 2004: 26. Also al-ANBĀRI (d. 577/1181) acknowledges the proposition of circa 70 definitions. Finally, the definition that is usually considered as most general among those provided by the Arabic grammarians is the one declared by al-SīRĀFİ (d. 368/978): "Everything that is the expression of what indicates a meaning not referring to a specific temporality, both past and other, is a noun" (kull šay' dalla lafz̧uhū 'alà ma'nan gayr muqtarin bi-zamān muhașșal min mudiyy 'aw gayrihī fa-huwa ism). Šarh, i: 53.

15 Several works deal with the presentation of the inherent features of the ism. For a general but accurate presentation, see especially EALL, ii: $424-29$ by BERNARDS and $E I^{2}$, iv: 179-182 by FLEISCH, both s.v. "Ism".

jais • 17 (2017): 332-344 
1505) who mentions ${ }^{16}$ a fourth category hălifa, ${ }^{17}$ and al-Farābī (d. 339/950), who proposes the category hawālif ${ }^{18}$ among others.

As a consequence of the stigmatization of the approach, grammarians were forced to frame several elements within a rather strict scheme and find a way to make their subdivisions fit the rules set for the tripartition.

Thus, elements differing from each other have been classified under the label 'noun', along with a set of sub-categories to indicate less obvious cases. The elements acknowledged as fully matching the definition of $i s m$ are: $:^{19}$ the common noun (ism al-gins), the proper noun (ism al-'alam), the concrete noun (ism al-'ayn), the abstract noun (ism al-

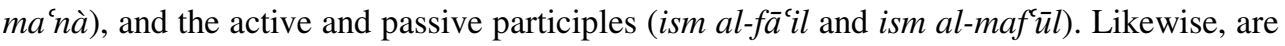
associated to the same category the adjectives (sifa), the infinitives (mașdar), the nouns referring to space and time (ism al-zamān wa'l-makān), the pronouns (muḍar), and the numerals (ism al-' ${ }^{\text {adad }}$. $^{20}$

Summaries of the debate on what may or may not be a noun are available in works such as Ibn Fāris' (d. 395/1004) al-Ṣāhibī:

As for the noun, Sībawayhi says: "The noun is for instance man and horse" [...], and Abū l'Abbās Muḥammad b. Zayd al-Mubarrad states that, according to Sībawayhi's view, "The noun is what can be a subject," [...] and al-Kisầ-1 states: "The noun is what an attribute can be referred to;" al-Farrä' says: "The noun is what can exhibit a tanwīn, be in construct state or annexed to the definite article;" al-Ahfaš says: "You know that you are dealing with a noun when a verb or an attribute can be referred to it, as for instance in zayd qāma (Zayd stood) or in zayd qä im (Zayd is standing), when it can be in the dual form or take the plural, as al-zaydāni (the two Zayds) and al-zaydūna (the Zayds), and when it exhibits a triptotic inflection." (fa-'ammā 'l-ism fa-qāla Sïbawayhi: "al-ism naḥw rağul wa-faras" [...] 'Abū 'l-'Abbās Muhammad bin Zayd al-Mubarrad yaqūlu madhab Sībawayhi 'anna "al-ism mā șalaḥa 'an yakūna fā'ilan" [...] wa-qāla al-Kisā̄̄i: "al-ism māa wușifa” [...] wa-kāna al-Farrā̄' yaqūlu: “al-ism mā 'ḥtamala al-tanwīn 'aw al-'id̄âfa 'aw al-'alif wa'l-lām” [...] wa-kāna al-'Ahfaš yaqūlu: "'id̄ā wağadta šay'an yahsunu lahu 'l-fi'l wa'ṣ-șifa naḥwa zayd qāma wa-zayd qā’im tumma wağadtahu yutnà wa-yuğma' naḥwa qawlik al-zaydān wa'lzaydūn țumma wağadta 'annahu yamtanic min-a 'l-taṣrîf fa-'lam 'annahu ism”). ${ }^{21}$

16 'Ašbāh, iii: 2.

17 Further information concerning the lexical category hălifa can be inferred from by the studies of Ahmmad Makkī al-Anșārī who investigates the role of al-Farrā' (d. 207/822) in the Arabic linguistic tradition as the leading figure of the grammatical school of Küfa. The author states that al-Farrä was the first who investigated and proposed a fourth lexical category between the noun and the verb. Hence, seems that the Küfan grammarian anticipated the modern studies on the topic, proposing a fourcategory division of the parts of speech, and overcoming the tripartition proposed by Sỉbawayhi. (Cf. alANȘĀRī 1964)

18 Zimmerman translates hawālif (plural of hālifa) with 'substitute', adding that it is used by al-Farābī as the equivalent of 'pronoun'. (Cf. ZiMMERMAN 1981).

19 See also WeHR and Cowan 1994, s.v. اسم (19).

20 For some grammarians, the interrogatives such as kayfa 'how', 'ayna 'where', and so forth, are to be included, too. Same for the 'asmä' al-'af'al 'verbal nouns', often labelled as nouns when meant as interjections or exclamation locutions, other than onomatopoeic.

21 al-ȘĀHIBĪ: 49. 
Yet, oftenthese reports are rather partial, as in the case of al-Mubarrad (d. 286/900) who, in the al-Muqtadab, declares a longer version than the one reported above, and also partly different. After defining the noun as ism mutamakkin, ${ }^{22}$ the grammarian proceeds by stating that:

A noun is everything that can be preceded by a preposition, and if it is not possible then it is not a noun. (kullu mā dahala 'alayhi harf min hurūf al-ğarr fa-huwa ism, wa-'in-i 'mtana'a dālika fa-laysa bi-'sm) ${ }^{23}$

Another significant definition is provided by al-Zağğāăğ (d. 311/923) and quoted by Ibn Fāris:

[The noun is] an articulated and comprehensible sound that expresses ${ }^{24}$ a meaning but has no implications ${ }^{25}$ of time and space (șawt muqața' mafhūm dāll 'alà mánan gayr dāll 'alà zamān wa-lā makān). ${ }^{26}$

Here the argument evolves from logic ${ }^{27}$ and concludes with a definition of the noun clearly influenced by the Greek tradition. ${ }^{28}$ The importance of his contribution lies in the different approach to the topic, more oriented towards the concept of the meaning of the noun.

\section{Ism: the discussion on etymology}

\subsection{The preliminary debate}

Being the definition of the category controversial also in the eyes of the Arabic grammarians themselves, ${ }^{29}$ semantics and etymology contribute to defining what ism is meant for.

Excerpts of the arguments and a summary of the theoretical development are reported in several grammatical works, such as al-Bāqillānī’s (d. 403/1013), al-'Ukbarī’s (d. 616/1219) and al-Anbārī's. The latter presents the issue on the etymology of ism in two major works, 'Asrār al- 'Arabiyya ${ }^{30}$ and the Kitāb al-'Inșā $f^{31}{ }^{31}$

22 According to the Kitāb, the category of the "mutamakkin" nouns refers to those elements that present peculiar features, may occur in various syntactic constrictions or have syntactic functions themselves, and may be inflected both in the determinate and in undetermined state. (Kitāb, ii:33; ii:40)

23 al-Muqtadab, i: 141.

24 Lit. 'it indicates'.

25 Lit. 'it does not indicate'.

26 al-ȘĀḤIBĪ: 51.

27 For an extensive and accurate study of the Greek influence on Arabic linguistic thinking, see Versteegh 1977.

28 As already examined by FLEISCH, it is clearly recognizable here the influence of Greek logic in the way the definition is articulated. The effects of the influence are so massive that we can also state that there is an almost sharp division between grammarians pre- and post al-Zağğāğ. Cf. FLEISCH, s.v. "Ism", $E I^{2}$, iv: $181-82$

29 ihtalafa 'n-nās fì 'l-ism wa-mimmā 'štiqāquhū, "People disagree on the ism and from what it is derived." al-BĀQILLĀNī 1957: 255.

30 'Asrār, 3-17.

jais • 17 (2017): 332-344 
The debate is presented through the examination of two hypothesized roots, namely $s$ $m-w$ and $w-s-m,{ }^{32}$ whose inherent meanings should be intended as practical explanations of the term and refer to the function attributed by the Arabic grammarians to the ism:

The Küfan grammarians argue that the ism derives from wasm, which indicates the 'mark', while the Bașran grammarians argue that it derives from simuww, ${ }^{33}$ which indicates the 'elevation' ${ }^{34}$ (dahaba 'l-küfiyyūn 'ilà 'anna 'l-ism muštaqq min-a ' $l$ wasm wa-huwa 'l-'alāma wa-d̆ahaba 'l-bașriyyūn 'ilà 'annahū muštaqq min-a 'ssimuww wa-huwa 'l-'uluww). ${ }^{35}$

According to these propositions, simuww-meaning 'elevation', 'height'-is coincident with the function of a ism identified with the signifier, whose role is to stay on a higher level than the signified below (al-musammayāt tahtahā). Conversely, Kūfan grammarians analyze the ism as derived from wasm (used as a synonym of 'aläma, 'mark'), and sima 'sign'. 36

The Kūfan grammatical school presents a reasoning related to the markedness theory: ${ }^{37}$

[ism] derives from wasm because in the language [of the Arabs] ${ }^{38}$ it indicates the mark, and a noun is a definition mark distinct from the symbol that identifies it [...]. For this reason, we assert that ism derives from wasm, and the same has been stated by $\mathrm{Ta}^{\mathrm{c}}$ lab who argues that the noun indicates the sign that has been established ${ }^{39}$ for

31 'Inșāf, 1-6.

32 The passages quoted below shall show that Arabic grammarians do not refer to roots when discussing the process of derivation (ištiqāq), but rather refer to words. As described by Larcher: "Dériver, ce n'est donc pas tirer un mot d'une racine, mais un mot d'un autre. Pour autant, les grammairiens arabes n'ignorent ni la racine ni la forme (ou schème). Si la forme est appelée ici d'un mot (șig̀a) qui en est un correspondant exact, il en va tout autrement de la racine, appelée ici tarkīb, c'est-à-dire «combinaison [de consonnes]». [...] Enfin, troisième et dernière différence: tout en dérivant d'une base concrète, les grammairiens n'ignorent pas, on l'a vu, le concept de racine, ni celui, corollaire, de forme. Par suite, la racine n'étant pas première, elle n'a pas de sens en elle-même, mais seulement comme trace de la base dans le dérivé." LARCHER 2008: 87, 90.

33 The Lisān al-'Arab also registers the variant as-sumuww. Cf. Lisān al-'Arab, xix: 121-128., s.v. samā (root $s-m-w)$.

$34 \mathrm{He}$ is not mentioned in the text, but the latter proposition seems to be shared also by al-ZAĞĞĀĞ. (Cf. al-Șāhibì: 57).

35 'Inșāf, 1.

36 Also 'mark', 'stigma'.

37 Mark is used here to recall the markedness theory, where the marks are grammatical elements (gender, number and case) and not lexical. According to this theory, the noun is not a mark. But, for the purpose of the translation, the word has been adopted under a generic — and not technical—profile.

38 The kaläm al-'arab is usually one of the main sources for grammatical observations. The reference is to the Arabic variety spoken by the Bedouins of the Arabic peninsula. The Arabs, whose unconscious knowledge of the language prescription is a manifest concept for every grammarian, are presented by early scholars as having an innate wisdom (hikma) which makes them choose the correct forms without being really aware of the grammatical reasons.

$39 t \bar{u} d a^{c}$, from $w a d^{c}$, indicating the creation of a name: "The phrase wad ' al-lugia which may be translated as the foundation of language, represents a concept that is central to classical Muslim scholarly thinking 


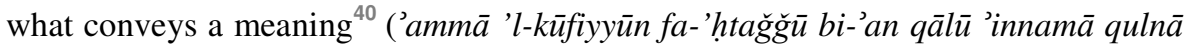
'innahū muštaqq min-a 'l-wasm li-'anna 'l-wasm fì 'l-lugia huwa 'l-'alāma wa'l-ism wasm 'alà 'l-musammà wa-'alāma lahū yu'raf bihī [...]. fa-li-hāda ā qulnā 'innahu

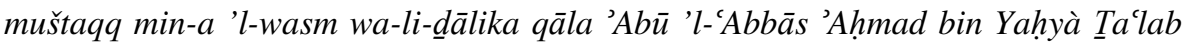
al-ism sima tūḍa' 'alà šay' yu'raf bihā). ${ }^{41}$

To prove the inherent meaning of 'height', 'elevation', semantics comes to adduce evidence: sumuww is an attested result inferred from the verb sama $\bar{a}$, уаsтū , sumuww, whose meaning is 'to be elevated':

The term derives from sumuww, because in the Arabic lexicon it indicates the elevation: when something is elevated you say samā, yasmī, sumuww. From this the sky has been called $s a m \bar{a}^{3}$ because it is in the height, and [likewise] the noun stands above the signified and shows what is below, as far as the meaning is concerned ('innamā qulnā 'innahū muštaqq min-a 's-sumuww li-'anna 's-sumuww fì 'l-lugia huwa 'l-'uluww yuqālu samā yasmū sumuwwan 'id̄a 'alā wa-minhu summiyat assamä' samäan li-'uluwwihā wa'l-ism ya 'lü 'alà 'l-musammà wa-yadullu 'alà mā tahtahū min-a 'l-ma'nà). ${ }^{42}$

Also, according to al-Mubarrad:

The noun refers to the nominatum below, but this argument is sufficient for the etymology, but it is not for the meaning. And since the noun is raised above the nominatum and stands above its meaning, this means that it is derived from sumuww and not from wasm (al-ism mā dalla 'alà 'l-musammà tahtahü, wa-hādāa 'l-qawl kāfin fí 'l-ištiquaq lā fì 'l-tahdīd fa-lammā samā 'l-ism 'alà musammāhu wa-'alā 'alà mā tahtahū min ma'nāhu dalla 'alà 'annahū muštaqq min-a 'l-sumuww lā min-a 'lwasm). ${ }^{43}$

\subsection{Grammatical observations on etymology}

Despite the evident logic behind the reasoning, it is evident that the opposition between $s$ $m-w$ and $w-s-m$ is merely speculative and part of a rather theoretical discussion.

The grammatical interpretation posing in contrast the two elements may be or may not be acceptable as a reasoning, ${ }^{44}$ but for the etymology there are many proofs showing that the Küfan interpretation is erroneous. Medieval Arabic grammarians pointed out the

about language. Language in that thinking was entirely invented. That is to say, it owed its existence to a process of deliberate assignment of patterned vocal utterances-or components of such utterances- to meanings, of 'alfāz ( $\rightarrow$ lafz) to ma'ānī ( $\rightarrow$ ma'nà)". WeISS, s.v. "Waḍ' al-Lugà", EALL, iv: 684.

40 This interpretation is also registered in the Lane: "A sign [such as may be uttered or written] conveying knowledge of a thing" - LANE 1863, iv: 1435.

41 'Inșâf: 1-2.

42 'Inșāf: 2.

43 'Inșāf: 2.

44 al-Anbārī himself agrees with the Kūfans on the strictly grammatical interpretation, although he does not agree on the etymology. 
uniqueness of the root through a grammar-oriented reasoning, as much as modern comparative studies do. ${ }^{45}$

Bașrans' confutation of Kūfan thesis is articulated in five passages, ${ }^{46}$ corresponding to the five modalities of mistake observed in their propositions. These arguments, four of which shall be examined in detail in the next paragraphs, ${ }^{47}$ conclude by demonstrating that despite the logic behind the Küfans' grammatical reasoning, there is one only possible root ism may be ascribed to: $s-m-w .^{48}$

\subsubsection{The form of the term}

The first analysis reported in the Kitāb al-'Inșâf refers to the form of the term ism and its phonetic realization, which results from the drop of the weak radical in the noun formation.

The Küfans state that the $w \bar{a} w$ occurring in the first position is dropped and replaced by a hamza $a^{49}$ which functions as a letter of compensation (ta $w \bar{l} \bar{d}$ ). If this phenomenon were productive, then the initial hamza would be a systematic result whenever a weak radical

45 The concept of root is a key element shared all throughout Semitic, and, as pointed out by VoIGT: "All Semitic languages have a verbal form and a nominal form (except for functional words and particles), characteristically consisting of a triradical root and a vocalic pattern which may also require the addition of further consonants" (EALL iv: 173-74). For the case study presented in this paper, other Semitic languages further substantiate the correctness of the arguments in favor of the root $s-m-w$, for they prove that a root, either biliteral or with a weak radical occurring in final position $[s(\breve{s})-m$ or $s(\breve{s})-m$ $w / y$ ], is attested all throughout Semitic. Hence, given the range of meanings: (1) 'noun', 'name', 'substantive' for Arabic ism, and (2) 'sky', 'heaven(s)' for Arabic samä', their cognates in other Semitic languages are, for example: Akk. (1) šumu, (2) šamü; Mehri (1) ham, (2) haytem; Jibbali (1) šem, (2) šutum; Gə`əz (1) səm, (2) samāy; Old South Arabian (1) sm, (2) $s^{l} m y n$ [Sabean], $s^{l} m h n$ [Minean]; Syriac (1) šomo, (1) šemā, (2) šmayyā; Biblical Aramaic (1) šm, (2) šmyn; Biblical Hebrew (1) šem, (2) $\check{s} m y m$. - In addition to those mentioned above, in Mehri and Jibbali are attested also the forms $s ə m \vec{\varepsilon}$ and $s i \bar{\varepsilon} h$, both clearly Arabisms, and in Soqoți is attested a coradical form e'ten carrying the same meaning. - As for Hebrew, it is worth mentioning that the Hebrew and English Lexicon (BROwN, DRIVER, and BRIGGS 2010) reports an 'unknown' root for the lemma שֶ, and lists among the cognates

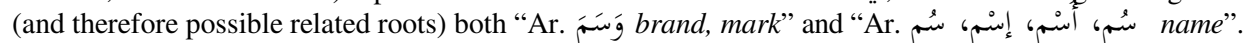
- Finally, the Dictionary of Semitic Inscriptions reports also the following attestations: "šm Sing. + suff. 3 s.f. šmh 10/ 9 - subst. name. šmyn Du. abs. šmyn 7/17; 12/14(*2), bšmyn 8/12, 11/12, 15/14, š[my]n 22/6; emph. šmy(') 10/2, 17/11,12; + suff. 3 s.m. šmwky 8/12, bšmwhy (bšmwhy ${ }^{\mathrm{m}}$ ) 16/14 subst. Du. heavens" (HOFTIJZER et al. 1995: 1265).

46 The arguments presented hereafter-mainly based on morpho-phonological observations-are meant to recapitulate grammarians' opinions as presented in al-Anbārì's Kitāb al-'Inșāf (Inșāf: 3-6). Similar-if not identical—arguments may be found in other works, too. One example is al-Bāqillānī who reports a more concise examination of the issue in the Kitäb al-Tamhìd (al-BĀQILLĀNī 1957: 255-257).

47 The fifth wrong argument presented by al-Anbārī shall not be analyzed here in detail, since it mainly proposes different variants of the term as registered in local Arabic varieties. The text mentions few different realizations of the term: ism, usm, sim and sum (ism bi-kasr al-hamza, wa-usm bi-dammihā, wasim bi-kasr as-sīn, wa-sum bi-d̦ammihā. 'Inșāf: 6). So, for instance, usm would be registered as of the tribes Tamīm and Qurayš. Besides, al-Anbārī briefly reports further explanations for some of the variants, as for sum, shaped on the pattern ' $u l$ from a proposed historical form "sumaw" with a consequential shift of the $w \bar{a} w$ onto a 'alif because of the vocalization in fatha of the preceding letter.

48 The arguments presented in §3.3.1-3.3.4 are also briefly mentioned in LANE 1863, iv: 1435.

49 Clearly a hamzat al-wașl, but it is always referred to as hamza only by the grammarians. 
occurred in the first position. Hence, in cases such as wa'ada the expected realization would be $*^{i} d$ ( $w a^{c} a d a-*^{i} d$ as in the pair wasama-ism).

Yet, the resulting terms reflect a different state of affairs, as the outputs of this type of roots would consist of terms ending with a $t \bar{a}^{\mathrm{P}}$ marbu $\bar{t} a$ (in fact the attested form derived from wa'ada is 'ida), as rightly stated by the Bașrans.

Bașrans consider the final $t \bar{a}^{\prime}$ marbutta as a compensation letter indicating the drop of the first - weak - radical, while the initial hamza would result from the drop of the last radical. Thus, ism derives from an underlying form *simw, shaped on the pattern $f i l$ where the first radical is vocalized in kasra and the second is quiescent. ${ }^{50}$ According to the Bașran proposition, in that instance the root would suffer from the drop of the third radical, and, resulting biliteral, would compensate the elision of the $w \bar{a} w$ by appending a hamza at the beginning of the word, on the paradigm if $f^{x}$.

\subsubsection{The past tense}

The second Başran proposition is about verbal analysis and how verbs are formed out of this type of root, starting with the mā $\bar{l} \bar{\imath}$ of the fourth form. The Bașrans argue that the underlying form of the verb is *asmawtu, but the wāw-which comes to be the third radical of the root and occurs here in the fourth position-undergoes a regular process of transformation, turning into a $y \bar{a}^{, 51},{ }^{51}$ resulting then in the form 'asmaytu. The proposed theoretical form, as well as the resulting one, shows that the weak radical does not occur in first position in the root, which otherwise would result in a fourth verbal form *'awsamtu.

The same phenomenon is also attested in the mudāric, where the vowel shift is usually very regular due to the vocalization pattern of the form ('af'ala-yuf'ilu), as in $y u^{c} \bar{l} \bar{l}$, yud' $\bar{c}$, and yusmī, inferred from the underlying forms *yu cliw $^{*}{ }^{*} u^{\prime} \mathrm{diw}$, and *yusmiw, and where a quiescent $w \bar{a} w$ is preceded by a letter vocalized in kasra. The phenomenon is very regular and is recorded whenever a quiescent $w \bar{a} w$ comes to occur in a position adjacent to a consonant vocalized in kasra, as for instance in $m \bar{q} q \bar{a} t, m \bar{l} \bar{a} \bar{d}$, and $m \bar{l} \bar{z} \bar{a} n$, whose underlying forms would be *miwqāt, *miw'ād, and *miwzān, inferred from al-waqt, al-wa'd, and alwazn.

\subsubsection{The diminutive}

Within the debate, also the formation of the diminutive contributes to the definition of the root. Considering the root proposed by the Küfans, $w-s-m$, the diminutive form of ism would result in the form *wusaym, where the first weak radical is retained. Yet, the variant attested for ism is sumayy.

The Arabic lexicon does not record a form containing a weak radical occurring at the beginning of the word, whereas it records a form with a last weak radical.

The word is ascribable to an underlying form *sumayw, on the paradigm fu'ayl, but having a $w \bar{a} w$ as its last radical it shifts into a $y \bar{a}^{3}$ : when a $y \bar{a}^{\prime}$ and a $w \bar{a} w$ occur together and the first letter is quiescent, then the $w \bar{a} w$ turns into $y \bar{a}^{2}$, resulting in a geminated form. This

50 On a pattern $\mathrm{R}_{1}-\mathrm{i}-\mathrm{R}_{2}-\varnothing-\mathrm{R}_{3}$.

51 Other examples from the text are 'alaytu and 'ad'aytu, from the underlying forms 'alawtu and *'ad'awtu.

jais • 17 (2017): 332-344 
paradigm is widely attested and productive, as demonstrated by common terms such as sayyid, ğayyid, and mayyit, whose underlying forms would be *saywid, *gaywid, and *maywit. $y \bar{a}^{3}$ being easier to articulate,$^{52}$ a shift of the $w \bar{a} w$ onto a $y \bar{a}^{3}$ is favored.

\subsubsection{The plural}

The last Bașran proposition concerns to the formation of the plural form of ism, for which two major forms are registered: 'asma $\bar{a}$ ' and 'as $\bar{a} m \bar{\imath}$. Both are derived from the root $s-m-w$ and cannot be ascribed to $w-s-m$, from which the resulting forms would be *awsām and *awāsim.

Of the two possible plural forms mentioned above 'asma $\bar{a}^{3}$ is more correct because of its major attestation and plausibility. Its underlying form is *'asmāw, which records a wāw occurring in the final position, and preceded by a 'alif $z \bar{a}$ ' $i d a$. In such cases, the $w \bar{a} w$ usually shifts into a hamza, as recorded in other examples such as sama $\vec{a}, k a s \vec{a}$, and $r a g ̆ a \vec{a}$ whose underlying forms would be *samāw, *kisāw, and *rağāw.

In addition to this, another proposition argues that the $w \bar{a} w$ undergoes a process of shift into 'alif, acknowledging the existence of an abstract form where the fatha occurring before the 'alif is triggered by a vocalized $w \bar{a} w$. The latter, when occurring in a vocalized form and preceded by a letter carrying a vocalization in fatha, must necessarily turn into a 'alif.

The conclusion would then be the combination of two 'alif, one added to the root and one deriving from the last radical. But being both quiescent they do not merge; therefore, the second 'alif turns necessarily into a hamza, both hamza and 'alif being two hawä'iyya ${ }^{53}$ letters.

\section{Conclusions}

The aim of this contribution was to present an overall view on how Arabic grammarians dealt with the issue of defining the root from which the Arabic term ism should be derived. It was inferred from the inventory of arguments discussed in early works and here presented through the words of a $12^{\text {th }}$-century scholar, that ism may be derived from two distinct roots: $w-s-m$ and $s-m-w$.

The history of the Arabic linguistic tradition shows that the speculative activities of grammarians belonging to the Baghdādi tradition, like al-Anbārī, often reiterate previously discussed arguments with a manifest orientation towards Bașran ones. Nonetheless, it is undoubtedly important that in retracing the development of Arabic linguistic sciences the debate itself becomes as important as the linguistic issue discussed, because of the methodological approaches proposed. Al-Anbārì's way to present the debate is a kind of storytelling, where the Bașran predominance is justified by the fact that the method of analysis they propose is better theorized and developed. Thus, strict methodological procedures and

'ahaff, lit. 'lighter'.

53 "al-hāwi <qui comporte un souffle> est un épithète de l" alif al-ğarsī: <celui qui produit un son> par opposition à l' 'alif support de hamza". CANTINEAU 1960: 24. 
a sophisticated attitude to the reasoning show a clear superiority of the Bașran group over its counterpart, as in the case study presented in this paper.

In fact, as discussed in paragraphs 3.2.1 through 3.2.4, it is evident how the discussion led by Küfan grammarians-despite its logic_-does not have very solid foundations, but rather presents a more speculative approach. Not considering the propositions on semantics, common to both groups and ascribable to a higher level of linguistic abstraction, Bașrans' arguments on morphological phenomena are more well-grounded, and properly explain why the term ism cannot be derived from the root $w-s-m$, contrary to what Küfans argue. Furthermore, cognates evidence that also in other Semitic languages the root is either biliteral or has a weak letter as its last radical, thus adducing an additional proof on a comparative level.

\section{References}

al-ANBĀRĪ. 1886. ('Asrār). 'Asrār al-'arabiyya. Edited by Seybold. Leiden: Brill.

—. 1913. ('Inșāf). al-'Inșāffī masā̄il al-hnilāf bayn al-naḥwiyyīn al-bașriyyīn wa'l-kūfiyyīn. Edited by Gotthold WeIL. Leiden: Brill.

al-ANSĀR̄̄, Aḥmad Makkī. 1964. Abū Zakarīyā al-Farrā' wa-madhabuhū fì 'l-nahww wa'l-lug̀a. Cairo: al-Mağlis al-A'là li-Ri'āyat al-Funūn wa'l-Ādāb wa'l-'Ulūm al-Iğtimā'iyya.

al-BĀQILLĀNī. 1957. Kitāb al-Tamhīd. Edited by Richard J. McCarthy. Beirut: Librairie Orientale.

BAALBAKI, Ramzi. 2008. The Legacy of the Kitab: Sibawayhi's Analytical Methods within the Context of the Arabic Grammatical Theory. Studies in Semitic Languages and Linguistics; v. 51. Boston: Brill.

BrockelmanN, Carl. 1908. Grundriss der vergleichenden Grammatik der semitischen Sprachen. Berlin; New York: Reuther \& Reichard; Lemcke \& Buechner.

Brown, Francis / Samuel R. DrIVER / Charles A. BRIGgS. 2010. The Brown-Driver-Briggs Hebrew and English Lexicon: With an Appendix Containing the Biblical Aramaic; Coded with the Numbering System from Strong's Exhaustive Concordance of the Bible. Reprinted from the 1906 ed. Peabody, Mass: Hendrickson Publishers.

CAntineau, Jean. 1960. Cours de phonétique arabe: suivi de notions générales de phonétique et de phonologie. Paris: C. Klincksieck.

CARTER, Michael. G. 2007. "Pragmatics and Contractual Language in Early Arabic Grammar and Legal Theory." In Approaches to Arabic Linguistics: Presented to Kees Versteegh on the Occasion of His Sixtieth Birthday, edited by Everhard DitTERS and Harald MotzKI, 25-44. Studies in Semitic Languages and Linguistics, v. 49. Amsterdam; Boston: Brill.

— . 2004. Sibawayhi. Makers of Islamic Civilization. London; New York: I.B. Tauris.

El-DAHDAH, Antoine. 1992. Dictionary of Universal Arabic Grammar: Arabic - English. Beirut: Librairie Du Liban.

$E I^{2}=$ The Encyclopaedia of Islam II. $2^{\text {nd }}$ edition. 12 vols. Leiden: Brill, 1960-2004.

FLEISCH, Henri. 2008. Traité de philologie arabe. Beirut: Dār al-Mašreq.

Guillaume, Jean-Patrick. 1988. "Le discours tout entier est nom, verbe et particule: Elaboration et constitution de la théorie des parties du discours dans la tradition grammaticale arabe." Langages, 23 (92): $25-36$.

jحis • 17 (2017): 332-344 
ḤASAN, 'Abbās. 2004. al-Naḥw al-wāfĭ. 4 vols. Cairo: Dar al-Ma'ārif.

Hoftizzer, J. / K. Jongeling / Richard C. Steiner / Bezalel Porten / A. Mosak Moshavi / CharlesF. JEAN. 1995. Dictionary of the North-West Semitic Inscriptions. Handbuch der Orientalistik. Erste Abteilung: Der Nahe und Mittlere Osten, 21. Bd., pt. 1-2. Leiden; New York: E.J. Brill.

IBN FĀRIS. 1963. (al-Sāhhibī). al-S̄ạhibī fì fiqh al-luğa wa-sunan al-'arab fī kalāmihā. Edited by Mușțafà al-ŠUuwAYMĪ. Beirut: Mu’assasat Badrān.

IBN ĞINNĪ. 1952. al-Hașẩiș. Edited by Muhammad 'Alī an-NAGGĀr. 3 vols. Cairo: Dār al-Kutub alMișriyya.

IBN MANZ̄ŪR. 1955. Lisān al-'Arab. 18 vols. Beirut: Dār Șādir.

Kamali, Mohammad Hashim. 2009. Principles of Islamic Jurisprudence. Petaling Jaya: Ilmiah Pub.

Lancioni, Giuliano / Lidia BetTini, eds. 2011. The Word in Arabic. Studies in Semitic Languages and Linguistics, v. 62. Leiden; Boston: Brill.

LanE, Edward William. 1863-1893. An Arabic-English Lexicon Derived from the Best and Most Copious Eastern Sources. 8 vols. London; Edinburgh: Williams and Norgate.

LARCHER, Pierre. 2008. "Dérivation arabisante et ištiqāq arabe: histoire d'un malentendu." In Regards croisés sur les mots non simples, edited by Barbara KALTZ, 85-94. Langages. Lyon: ENS Éditions.

LEVIN, Aryeh. 1986. "The Medieval Arabic Term Kalima and the Modern Linguistic Term Morpheme: Similarities and Differences." In Studies in Islamic History and Civilization in Honour of Professor David Ayalon, edited by Moshe SHARON, 423-46. Jerusalem: Leiden: Brill.

al-Mubarrad. 1965. (al-Muqtadab). Kitāb al-Muqtadab. Edited by Muhammad 'Abdalhāliq 'UDAYMA. 4 vols. Cairo: Dār al-Taḥrīr.

SīBAwAYHI. 1966. (Kitāa). al-Kitāb. Edited by 'Abd al-Salām Muhammad HĀrūN. 5 vols. Cairo: Maktabat al-Hānğīi.

al-SīrĀFī. 1986. (Šarhh). Šarḥ Kitāb Sībawayhi. Edited by Muḥammad Hāshim 'ABD AL-DĀYIM. Cairo: al-Hay'a al-Mișriyya al-'Āmma lil-Kitāb.

Suleiman, Yasir. 1999. The Arabic Grammatical Tradition: A Study in Ta 'līl. Edinburgh: Edinburgh University Press.

al-SUYŪṬī. 1940. ('Ašbāh al-'Ašbāh wa'l-nazạảir fì 'l-nahw. 2nd ed. 4 vols. Hyderabad: Maṭba'at Dā’irat al-Ma'ārif al-'Utimāniyya.

al-'UkBARĪ. 1992. Masāil ḩilāfiyya fì 'l-naḥw. Edited by Muḥammad Hูayr al-ḤulwāNī. Beirut: Dār al-Šarq al-'Arabī.

Versteegh, C. H. M. 1977. Greek Elements in Arabic Linguistic Thinking. Studies in Semitic Languages and Linguistics; vol. 7. Leiden: Brill.

VERSTEEGH, Kees. 1995. The Explanation of Linguistic Causes: Az-Zağğăğğ’s Theory of Grammar. Amsterdam Studies in the Theory and History of Linguistic Science Ser. 3, Studies in the History of the Language Sciences; vol. 75. Amsterdam: Benjamins.

— / Mushira EID (eds.). 2009. (EALL). Encyclopedia of Arabic Language and Linguistics. 5 vols. Leiden; Boston: Brill.

WeHR, Hans / J. Milton Cowan. 1994. A Dictionary of Modern Written Arabic: (Arabic - English). 4th ed., considerably enl. and amended by the author. Spoken Language Series. Urbana, IL: Spoken Language Services.

Weninger, Stefan / Geoffrey Khan / Gerold UngeHeuer / Herbert Ernst WiEgAnd (eds.). 2011. The Semitic Languages: An International Handbook. Handbücher zur Sprach- und Kommunikations- 


\section{Simona Olivieri}

wissenschaft $=$ Handbooks of linguistics and communication science $=$ Manuels de linguistique et des sciences de communication / mitbegr. von Gerold UngeHEUER. Hrsg. von Herbert Ernst WIEGAND; Bd. 36. Berlin: De Gruyter Mouton.

al-ZAĞĞĀĞ. 1971. Mā yanșarif wa-mā lā yanșarif. Edited by Hudā Mahmūù QARĀćA. Cairo: Mațābic al-Ahrām.

Page I 344 Zimmerman, Fritz W. 1981. Al-Farabi's Commentary and Short Treatise on Aristotle's "De interpretatione" (translation, introduction \& notes). London: British Academy.

(C) Simona Oliveri, University of Helsinki / Finland \simolivieri@gmail.com $\downarrow$ 